Ana Leonar Pereira João Rui Pita

Pedro Ricarda Fonseca (eds.)
Darwin,

Evalution,

Evolutionisms

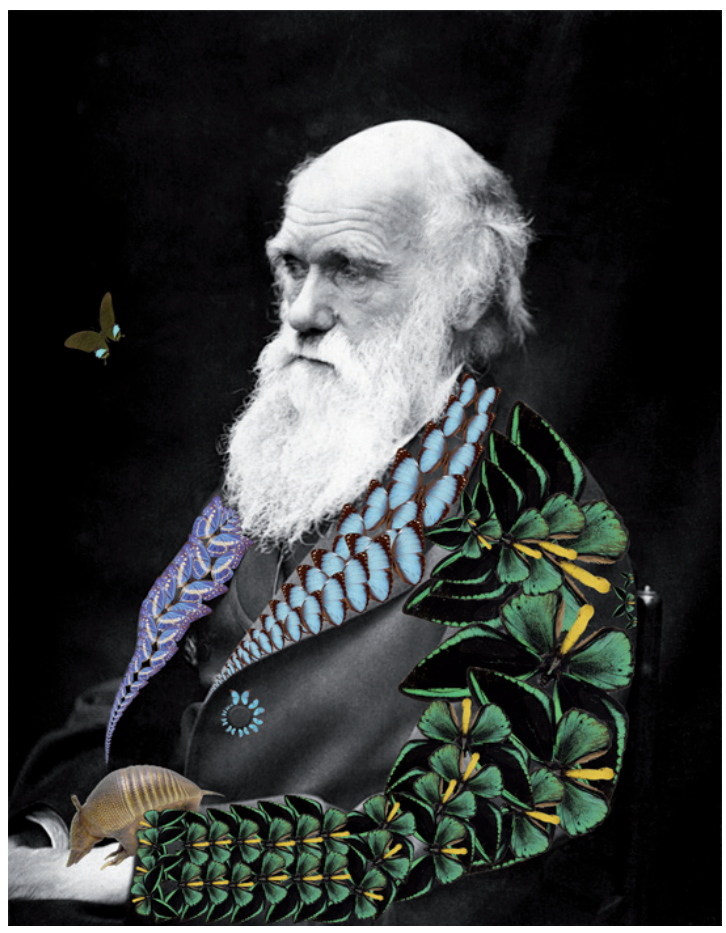


José Fonfría Díaz

Departamento de Biologia Celular, Facultad de Biologia, Universidad Complutense, Madrid, España

Alfredo Baratas Díaz

Departamento de Biologia Celular, Facultad de Biologia Universidad Complutense, Madrid, España

\section{Darwinism in La REVISTa EURopea}

Even though in Spain there had been references to Darwin's ideas before the Glorious Revolution of 1868, mainly critical references, the public debate did not appear until the Republican stage, coinciding with a period of scientific recovery (López-Ocón, 2003) in which censorship was abolished and freedom of speech and academic freedom prevailed (Núñez, 1977; Sala Catalá, 1987). The penetration of Darwinist ideas was so important during the Six-Year Revolution (1868-1874) that, apart from the exclusion that many of his divulgers faced during the Restoration (1874-1924), it was impossible to avoid its continuity (López-Ocón, 2003).

However, the appearance of Darwinism in Spain was characterised by strong controversy whose virulence was due to, as Núñez (1977) has said, the inmeasurable degree of illiteracy in Spanish society, the strong economic and political division, a powerful Church allied with conservative powers, reluctant to any idea which could contradict the Biblical text, and the precarious situation of Spanish society.

Taking into account the appearance of Darwinist evolutionism in Spain, it is important to mention the important role played by the intellectual Krausists who accepted and adapted evolutionism to their ideological assumptions (Blázquez Paniagua, 2007). The Krausists had a crucial importance in Spanish thought, culture and science in the second half of the $19^{\text {th }}$ century and the first third of the $20^{\text {th }}$ century, both directly and indirectly. In a direct way, inspiring the political reforms of the Six-Year Revolution; indirectly, through the investigation and education institutions which were created or promoted, such as the Institución Libre de Enseñanza or the Junta para Ampliación de Estudios e Investigaciones Científicas (Baratas, 1997).

On the other hand, the divulging of Darwin's ideas was especially carried out through Ernst Haeckel's (1834-1919) works and articles. Haeckel's ideas rooted among the Krausists, through the discovery of a form of relating positivism with the idealistic philosophy in his Monism as a complete response to the mysteries of the Universe. If the Krausists had defended an idealistic Monism, it was now a positivist, scientific Monism; but the Monist philosophy and the anticlericalism fully clashed with the Orthodoxist Catholicism (Núñez, 1996).

These facts have determined that the line that separated creationists and Darwinists was the same that separated clericals from anticlericals and conservatives from liberals. Darwin became, for some, the archetype of progress, modernity and science, and for others, the representative of anticlericalism, materialism and atheism. 
A proof of those debates can be observed in the short life of the Revista Europea, published weekly from its first number on March 1st, 1874, to January 1880, included, when it then passed on to be published twice a month, appearing during its last five months, on the 5 th and 20th day of each month.

The Revista Europea represented one of the pillars of the philosophical reform of the Spanish language created during the last decades of the $19^{\text {th }}$ century. In it, the predominate idea was the interest for positivism and evolutionism and the translations of abundant texts belonging to E. Haeckel, Herbert Spencer (1820-1903), Thomas Henry Huxley (1825-1895), John Tyndall (1829-1893), Karl Vogt (1817-1895), Geroge John Romanes (1848-1894), etc. even though some written texts were published from different perspectives such as those following Neokantianism, Neohegelians, Krausists, etc..

The first reference to Darwin that appears in this magazine is a review of a meeting of the Société de Géográphie of Paris, in which M. Simonin, in an obvious demonstration of social Darwinism, justified the control of the indigenous peoples of North America in reserves as a consequence of the "fight for existence, in which the inferior races yield with the simple contact of the civilised races" (nbr. 11, pg.350).

In number 55 (March 14th, 1875), Herbert Spencer signed an article, La creación y la Evolución (Creation and Evolution), in which, after proving the inconsistency of the hypothesis of special creations and pointing out a series of facts in favour of evolution, considers that "under all those points of view the hypothesis of Evolution contrasts in a favourable way with the hypothesis of Special creations" (nbr. 55, pg. 72).

On the other hand, number 114 (April 30th, 1876) included an article signed by Carlos Martins, which had been published in the French magazine Revue des Deux Mondes, in which much evidence was presented in favour of evolution, defending Lamarck's approaches, without citing Darwin at any moment.

Number 136 (October 1st, 1876) includes a study belonging to T. H. Huxley centred on the Protists (On the Border Territory between the Animal and the Vegetable Kingdoms) which helps us detect the evolutionist thoughts of its author, the same as On the Study of Biology published in number 231 (July 28th, 1878), even though they are not articles especially dedicated to the defense of evolutionist positions.

This defense does appear in Karl Vogt's article on El origen del hombre, (The origin of man), published in sequences in numbers 193, 194 and 195 (November 4th, 11 th and 18th, 1878), in which he defended the phylogenetic relation between man and monkey through an extensive study of comparative anatomy.

Even clearer in its support of the Evolutionist ideas is the article of the French Physiologist and Anthropologist, Nicolás Joly (1812-1885), La especie orgánica considerada bajo el punto de vista de la taxonomía, (The organic species seen under de taxonomical point of view) published in number 217 (April 21st, 1878) and, most of all, in a subsequent article, Las formas transitorias de las especies (The temporary forms of the species) in numbers 226 and 227 of June 23rd and 30th, 1878, in which he confirms the existence of intermediate species between the actual ones and the analogous of the fossil record, opposing Cuvier's ideas. Taking into account the origin of these forms, he asks "were they virtually found included in the organogenic laws? What was carried out when the fixed moment for its emergence came? Or finally, were they produced under the triple and powerful influence of natural selection, of succession 
and of the surrounding environment?", answering that "This last alternative seems more probable to us though we still do not see ourselves authorised to say the most genuine one".

According to the main line of the magazine, the most important contribution in support of the Darwinist theory is due to the German Naturalist Ernst Haeckel. It starts with an article named La teoría de la evolución en sus relaciones con la filosofía natural, (The Theory of Evolution in its relation with Natural Philosophy) published in two sequences, (nbr. 204 and 205, of January 20th and 27th, 1978), without mentioning the translator. In it, besides defending the theory of natural selection and its application to the human species, and of expressing the victory of scientific Monism over Dualism, it presents the necessity of introducing "the main principles of the doctrine of evolution" in schools.

In this same year, 1878, another seventeen of Haeckel's articles were published; all translated by the naturalist Claudio Cuveiro. The series started with Sentido y significación del sistema genealógico ó teoría de la descendencia (Sense and meaning of the geonological system or theory of descent) (number 228, July 7th) and is continued with revisions of the creationist assumptions of Linneo, Cuvier and Agassiz (numbers 229 and 230, 7th and 14th of July, respectively). Following that, we can observe a revision of all the Evolutionist theories (numbers 231 to 233), dedicating special attention to all questions related to the Darwinist theory (numbers 234 to 242). In the last one Leyes del desarrollo de los grupos orgánicos y de los individuos. Filogenia y ontogenia, (Laws on the development of organic groups and individuals. Phylogeny and ontogeny) considered the importance of deepening the establishment of the correct genealogy of the different groups of living beings.

This issue was developed in six extensive articles, also translated by Claudio Cuveiro, that appeared in sequences in different numbers of this magazine. The series started with Árbol genealógico é historia del reino de los protistas (Genealogical tree and history of the Protists' Kingdom) (numbers 254 and 255) and continued with Arbol genealógico ó historia del reino vegetal (Genealogical tree or history of the Vegetable Kingdom) (numbers 257 and 258), Árbol genealógico é historia del reino animal (Genealogical tree and history of the Animal Kingdom) (numbers 259 to 266) and Origen y árbol genealógico del hombre (Origin and genealogical tree of man) (numbers 267 and 268). Shortly after, an article dedicated to the Emigraciones y distribuciones del género humano. Especies y razas humanas (Emigration and distribution of the human gender. Species and human races) appeared in numbers 269, 270 and 272, including a taxonomic scale with twelve human species. The series finishes with Objeciones contra la verdad de la doctrina genealógica y pruebas de esta teoría (Objections to the truth of the genealogical doctrine and evidence of this theory) (number 273) in which he defended the application of the Darwinist theory in order to establish the genealogy of man for "The evolutionist doctrine gives a purely natural explanation of the origin of man and of the course of his historical evolution and, in my idea the progressive elevation of man through the inferior vertebrates is the greatest success that human nature has obtained over all of its nature" (nbr. 273, pg. 626).

In number 267 (April 6th, 1879) Oscar Schmidt exposes Una controversia transformista (A transformist controversy) between Virchow and Haeckel on the "theory of descent", centred specially in the origin of man, supporting Haeckel's position.

In number 175 (July 1st, 1877) an article signed by G. Gueroult reviews the French translation of the text corresponding to the Philosopher E. Hartmann (1842-1906) 
with the title Le darwinisme. Ce qu'il y a de vrai et de faux dans cette théorie. In his analysis, Gueroult considers that "natural selection plays a role, but a relatively secondary role; it is, in a certain way, the moderator of the liveliness of evolution" (pg. 22).

Number 6 (April 5th, 1874) included an article of the Belgian Geologist J. B. J. d'Omalius d'Halloy (1783-1875) in which he defended the possibility that organisms may modify themselves according to the circumstances, but due to a type of divine design.

Even though it only has an indirect relation with Evolutionism, it is interesting to highlight the publication in number 184 (September 2nd, 1877), of an article signed by Darwin with the title Los preludios de la inteligencia. Bosquejo biográfico de un niño. [The preamble of intelligence. A biographical sketch of an infant]. It is a translation of an article published in Number 7, Volume 2 of the magazine Mind in 1877, with the title A Biographical Sketch of an Infant. In this article, Darwin describes a series of observations on the initial processes of the cognitive development of one of his sons. Since Darwin mentions that these observations had been carried out 37 years ago, it is unquestionably his son William Erasmus, born in 1839 .

Among the articles contrary to evolutionist ideas we can differentiate two groups: those signed by naturalists, who try to justify their position with more or less scientific reasonings and those who come from the Philosophical field who, generally, show clearly idealistic positions.

Among the first we can find in number 10 (May 3rd, 1874), an article of Louis Agassiz (1807-1873), El tipo especifico, (The specific type) in which he denied the validity of the evolutionist theory by natural selection insisting mainly in the non-existence of temporary forms in the fossil record, for which "in the geological succession of animals there is no proof that the relatively modern species come directly from those of remote antiquity" (pg. 309).

The Spanish Geologist and Paleontologist Juan de Vilanova (1821-1893) published, between number 40 (November 29th, 1874) and number 116 (May 14th, 1876), a series of articles on Paleonthology with the title Ciencia prehistórica (Prehistoric Science) based on his lectures as professor, in which you can clearly observe his membership to the field of the Catastrophics. The second to last of these articles, published in number 114 (April 30th, 1876) was dedicated to La doctrina de Darwin (Darwin's Doctrine). In it, he shows his resistance to the thought of Darwin's followers because "Starting from the most genuine representatives of this doctrine of the hypothesis of the eternity of the material, who think, without proving enough evidence in its favour, that this is enough to produce on its own the life represented by vegetables and animals, starting from the most simple organism or Protists, which, obeying certain laws, named of selection and competition for life, are supposed to have been improving and transforming one another/... But it is the case that, arriving to the actual moment, we observe that each species only produces beings similar to them, without any intermediate ancestor to which the theory appeals in order to explain the origin of the diverse organisms" (pg. 357), and affirmed a catastrophic criteria based on the lack of intermediate forms.

In the same line we can also take into account an article of the Botanic E. P. Fournier (1834-1884), Los centros de creación y la aparición sucesiva de los vegetales (The centres of creation and the successive emergence of vegetables) (nbr. 104, February 20 th, 1876), in which he criticises the theory of the centres of creation exposed by A. Grisebach (1814-1879) and substituted it with the successive creations. 
From the philosophical field, the Hegelian Philosopher A. M. Fabié (1832-1899) published a series of 10 articles, with the title Examen del materialismo moderno, (Examination of modern materialism) which was distributed between numbers 40 (November 29th, 1874) and 53 (February 28th, 1875), all marked with an idealistic character. The article on number 43 (20th of December) was dedicated to Darwinism. He presented himself as an evolutionist but accepting Lamarck's approaches against the "struggle for existence" and "natural selection", among other reasons because "if there were a natural selection, this would show each individual passing on to its offspring those organic modifications which make them more suitable to accommodate themselves to the environment and not those that give them advantage in their fight over its similar or with other organised beings" (pg. 229). Consistently, the following number (January $3 \mathrm{rd}, 1875)$ was dedicated to criticize all of Haeckel's work.

In number 257 (January 26th, 1879) an article was initiated, continuing with numbers 259 (9th of February), 263 (9th of March) and 264 (16th of March), signed by L. Carrau with the title El darwinismo y la moral, (Darwinism and morality) in which he accepted the evolutionist character of animals' social instinct but denied that moral sense could have been achieved by man through a progressive process during his history.

On the other side, M. Guyan signed, in number 272 (May 11th, 1879), the article, La moral del darwinismo, (The morality of Darwinism) in which he accepted, with certain precision, the evolutive origin of morality, for he considered that, with Darwin's work, "the empirical genesis of the moral conscience would have never been carried out in such a remarkable way. The theory of natural selection offers a serious confirmation of the inductive morality. This production of the conscience through instinct appears in the mental chemistry as a sign of progress similar to that which has recently carried out the physical chemistry forming with inorganic and organised bodies, producing vegetable substances with minerals, almost creating the plant with the rock".

\section{Bibliography}

BARATAS DÍAZ, L. A. (1997). Introducción y desarrollo de la biología experimental en España entre 1868 y 1936. Madrid, Consejo Superior de Investigaciones Científicas.

BLÁZQUEZ PANIAGUA, F. (2007). Notas sobre el debate evolucionista en España (1900-1936). Revista de Hispanismo Filosófico, 12; 1-19.

LÓPEZ-OCÓN, L. (2003). Breve historia de la ciencia española. Madrid: Alianza Editorial.

NÚNEEZ, D. (1977). El darwinismo en España. Madrid, Castalia.

NÚÑEZ, D. (1996). La religión y la ciencia. Mundo científico, 166, 247-263.

SALA CATALÁ, J. (1987). Ideología y ciencia biológica en España entre 1860 y 1881: la difusión de un paradigma. Madrid, Consejo Superior de Investigaciones Científicas. 